Article

\title{
Events and Tourism Development within a Local Community: The Case of Winchester (UK)
}

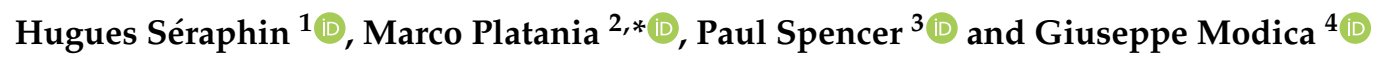 \\ 1 Business School, University of Winchester, Winchester SO22 4NR, UK; hugues.seraphin@winchester.ac.uk \\ 2 Department of Educational Science, University of Catania, 95124 Catania, Italy \\ 3 Faculty of Arts, University of Winchester, Winchester SO22 4NR, UK; paul.spencer@winchester.ac.uk \\ 4 Dipartimento di Agraria, Università degli Studi Mediterranea di Reggio Calabria, Località Feo di Vito, \\ I-89122 Reggio Calabria, Italy; giuseppe.modica@unirc.it \\ * Correspondence: marco.platania@unict.it
}

Received: 10 August 2018; Accepted: 12 October 2018; Published: 16 October 2018

check for updates

\begin{abstract}
Tourism as an industry has many kinds of impacts on destinations and their communities. The presence of tourism could create the conditions for an economic development but in the same way produce negative effect (crowding out) and externalities (the Janus-face character). Between the different actors inside the tourist destination, there are the local community which could endure the pressure of tourism. In some cases, this pressure reduces the wellbeing of the residents. The present research paper focuses on how activities like events and tourism impact on community well-being. Winchester (England), a Special Interest Tourism and Event (SITE), is used as a case study. The data are collected using an on-line interview and they are elaborated using multivariate techniques and ordinal regression analysis. The results of the study reveal a close relation between the level of happiness of the local residents and their perception of the tourism industry and event development. Local residents in Winchester are perceiving the tourism industry and events rather positively as they believe it supports their culture and the local economy and job in particular. Our first overall conclusion is that there is a relationship between the residents' happiness and tourism/event perception. Moreover, our findings support what claimed by several scholars that tourism specialisation improves the residents quality of life (QOL). The present study has not shown the direction of the influence but according to previous research it is the level of happiness of the local residents that determines their perception of the tourism industry and event development and not the other way around. The second finding of the study reveals that SITE destinations have a high potential in terms of contributing to the local residents' happiness and subsequently visitors. Our third and final conclusion is that, when the benefits of tourism and events are higher than the cost, local residents and are likely to be supportive of the activity.
\end{abstract}

Keywords: wellbeing; happiness; tourism; events; Special Interest Tourism and Events (SITE); local community

\section{Introduction}

It is now common knowledge that tourism as an industry has positive and negative impacts on destinations and their communities [1,2]. This can be explained by the Janus-face character of the industry [3,4]. Among the negative impacts of the industry, we can point out over-tourism. Indeed, over the summer 2017, this became a major issue, particularly across Europe. Many anti-tourism movements arose because of over-tourism, as well as suggestions to cope with this issue $[5,6]$. Some were incremental like increasing tourism taxes and others were more radical like Trexit (tourism exit). More importantly, Seraphin et al. [6] explained that over-tourism might cause in the very nearer future the fall of some destinations such as Venice. In addition, two key points are raised. First, 'sustainability in tourism is 
something that has yet to be achieved with the industry not fully comprehending how it is in fact to be achieved' ([6]: p. 373). Second, tourists and tourism when poorly managed can contribute to local communities' unhappiness [6,7]. In this research paper, we are going to focus on the latter key point.

Happiness can be recognised as a fundamental societal metric [8]. Moreover, residents' happiness index is a vital indicator of the sustainability (economic, social and environmental) of a destination that contributes to the competitive advantage of the destination as there is a strong connection between tourism development and local residents' happiness [9]. On that basis, Croes et al. [8] explained that destinations must become a facilitator of happiness for locals and Ivlevs [7] even claimed that tourist arrivals can reduce residents' life satisfaction. This negative relationship tends to be more evident in countries where the intensity tourism is relatively high. Moreover, tourism researches tend more to focus on the satisfaction of tourists rather than of residents [7,10-12]. Moreover, there is a gap of literature regarding service consumption practices and their effect on the well-being of consumers [13]. This research is going to contribute towards filling this gap in the literature. To do so, we carried out a survey in Winchester, a Special Interest Tourism and Events (SITE) destination in the south of England (Figure 1). It is also worth mentioning that England as a destination is not well researched. As for Winchester and the wider county of Hampshire, there is no academic based research. This is another gap that this research is addressing. Finally yet importantly, there is a need for further research on how and whether tourism contributes to the host's life satisfaction, because each destination is unique and it is important to test different types of behavioural reactions and responses [11]. The present paper offers a scientific contribution also in this direction.

In this paper, the research question is as follows: How can activities like events and tourism (which are service activities, recreational and leisure activities, etc.) impact on community well-being? By answering these questions, we define the research objectives that are understand what the perception of the tourism sector among Winchester residents is and how specific types of tourism and events impact on local residents' subjective well-being. This question is extremely important if we consider that life satisfaction of residents tends to decrease with tourist arrivals to a greater extent than the subjective well-being of their urban counterparts' life satisfaction of residents tend to decrease, as Ivlevs [7] claimed. We have also to consider that Winchester is a cultural, heritage and a family destination. As Uysal et al. [12] explained, cultural tourism is positively related to residents' overall life satisfaction, alongside health, wealth and safety of the community. In addition, the results of our findings can support or contradict Croes et al. [14] findings who claimed that 'tourism specialisation improves the residents quality of life (QOL) but only on the short term'.

The structure of the paper is as the follows. In the first part, we present some theoretical suggestion based on the analysis of literature research. Then, we present the case study and describe the characteristics of the questionnaire. As for the contextual framework, it gives a specific insight of Winchester as a destination. In terms of methodology, this paper is based on primary data collected using a questionnaire and elaborated using multivariate techniques and ordinal regression analysis. The results and discussion sections present the results of the questionnaire and provide an analysis of the latter. Limitations and future directions for research will also be identified. Finally, in the conclusion section, some recommendations for managerial action [15] are provided.

\section{The Multiform Concept of Wellbeing}

\subsection{The Quality of Life (QOL)}

According to several scholars $[14,16,17]$, the concept of quality of life (QOL) can be defined as a person's life satisfaction or dissatisfaction, happiness or unhappiness, or as a sense of psychological or subjective well-being. Hobson and Dietrich [18] state that there is an "underlying assumption in our society that tourism is a mentally and physically healthy pursuit to follow in our leisure time," meaning that tourism is a factor increasing the QOL. Referring to the subjective well-being, the most frequently 
used representations are life satisfaction and happiness are the most frequently used representations of subjective well-being in the academic literature' [7].

Also, it is important to mention the fact that QOL and well-being are interchangeable terms [19]. It is equally important to mention that life satisfaction is influenced by variables such as: age; gender; household size; family structure; level of education; income [20]; job security; economic context of the destination; geopolitics; level of security of the destination and the weather [7]; Human Development Index; Gross Domestic Product; environment factors [21]; health; family; friendship and sentimental situation [11].

The academic research evolved happiness meaning 'from materialistic conceptions (money buys happiness) to satisfaction of desire to the fulfilment of one's capacities to do what one appreciates in life (Aristotle's eudaimonia)' [22]. In this sense, Lyubomirsky and Lepper [23] consider happiness to be one of the most important human dispositions and therefore an essential aspect of the quality of life. If happiness is now 'considered to be the proper measure of social progress and the goal of public policy' [24], it is only recently that it gained that much importance. Indeed, the first World Happiness Report was published only in 2012 [24]. In 2017, Norway topped the global happiness ranking. Caring, freedom, generosity, honesty, health, income and good governance are the factors that supported the happiness of Norwegians [24]. There are some countries in which all national policies, including those for tourism sector, are rooted in a happiness strategy [25]. These factors do not differ much from the ones listed earlier. Health, income and good governance seem to be recurrent factors in all studies on that topic.

The importance of the life satisfaction is supported by Bimonte and Faralla [11] who claimed that despite the fact there has been much research on resident perceptions and attitudes of tourism, that probably started with Butler's Tourist Area Life Cycle and Doxey's Irridex, 'no study focused on life satisfaction of residents as the ultimate dependent variable to establish the link between perceive impact of tourism and satisfaction with the life domains in the destination community' [11]. This issue is confirmed also by Kim et al. [9] whose state that "tourism impact on community residents' well-being may vary significantly as a direct function of the stage of the community in the tourism development life cycle."

Bimonte and Faralla [11] have clearly established that tourism contributes to the host's life satisfaction. Indeed, they provided evidence that if during off peak seasons residents' happiness is influenced by a range of factors, namely: income and work; health; family; friendship and sentimental situation, during the peak season, elements like: home environment; overcrowding; price increase and quality of life become very important when residents evaluate their level of happiness. Moreover, Bimonte and Faralla [11] summarise the connection between tourism and residents' happiness as follow: 'residents perceive tourism as a dual phenomenon. While aware of its major economic role and importance as a source of income, they admitted that it affected some aspects of their everyday life, worsening their perceived quality of life. The perceived impact increases with the tourist season (... ) Therefore, tourism makes residents wealthier but, during the tourist season, less satisfied with their lives ( . . ) this does not necessarily mean that people are actually less satisfied with their lives as a whole'. In the same meaning, Kim et al. [9] state that ' ... when residents perceive the positive economic, social and cultural impact of tourism, satisfaction with related life domains (sense of material, community and emotional well-being) increases too. However, when residents perceive the negative environmental impact of tourism, their sense of health and safety decreases as a result'. This is further supported by Ivlevs [7] who claimed that tourist arrivals reduce life satisfaction and also argued that scientific literature is addressing the impacts of tourism on residents' quality of life and its various manifestations. In this direction, Uysal et al. [12] highlighted that in the last few decades QOL research is an emerging field of study in the social, behavioural environmental and policy sciences. From a practical point of view, these researches are important in supporting Destination Management Organisations (DMOs) to prevent conflicts among locals and visitors similar to what happened over the summer of 2017. This is all the more important as tourism involves at least guest and host communities, while locals are an indispensable partner for the success of any tourist programme [26]. According to Crouch \& Ritchie [27], the destinations that try to improve their competitive position should develop a parallel capability to better serve the residents and consequently the enhanced competitiveness of the destination should lead to a sustainable improvement in the QOL of these same residents. From an academic point of 
view, beyond filling an existing gap in literature, the present research is adding more ground to existing research, which is quite important because the effects of tourism on hosts' lives is not unanimous.

\subsection{Festivals and Community Quality of Life (QOL)}

Van Niekerk [21] and Yeoman et al. [28] explained that festivals as a sector of the event industry is booming, as a result it is impacting on local communities either positively or negatively (socio-cultural; physical and environmental; political; tourism and economic impacts). Research on the sustainability of festivals and events is relatively advanced. The main topics concern studies on the impact of festivals and events on the sustainability of destinations and host communities; the planning of sustainable festivals and events; and strategic objectives of the festival and event organisers linked to sustainability results [29]. While the benefits of tourism from the events were initially expected to be obvious [30], recent research has suggested that event results are maximized only if the strategies are designed to achieve the stated tourism objectives [31]. The destinations try to exploit events to ensure a competitive advantage in the market and to reach the destination objectives [32]. This means that event tourists who stay longer in the destination are more profitable and reduce impacts. For example, through the events it is possible to optimise limited resources and distribute benefits of the event over a wider area [31].

One of the key contributions of events to a community is its ability to develop a sense of belonging through bringing people together to share participating in various activities [33], while, according to Van Niekerk [21], no research has investigated the impacts of festivals on resident QOL although they are one of the most important stakeholders' group. In that direction, working at the Innibos National Art Festival in South Africa, Van Niekerk [21] showed that the way to obtain a positive attitude of local communities toward the festival is to involve them in planning and organise the festival. Summarising, events are increasingly important for main reasons: a significant degree of flexibility, compared to certain types of physical infrastructures; contribution in differentiating physical environments [34].

\subsection{Tourism and Quality of Life (QOL) of Residents: Anatomy of the Investigated Phenomenon}

In order to delimit the scope of the investigation, we also provide an analysis of tourism management articles referring to happiness and well-being. To this aim, we considered the 15 journals in tourism listed in the Journal Quality List edited by Professor Anne-Wil Harzing on 18 April 2016. Once articles are identified and analysed (name of authors; date of publication; title of the article; name of journal; research object) we will be able to determine the anatomy of the investigated phenomenon. This protocol is an adaptation of the protocol adopted by Seny Kan et al. [35] when delimiting the scope and anatomy of Qualitative Comparative Analysis (QCA) in management research.

The results of the literature review (Table 1), using the sample journals listed in the previous paragraph show that research in the area of tourism and happiness/well-being is quite recent. The first one was published in 2008. Between 2008 and 2018, the average number of papers published is two per year, with 2017 being the year with the most publications. This literature review also reveals that the vast majority of papers is focusing on the happiness and well-being of tourists. Only three are focusing on the happiness and well-being of residents/local communities and all published in 2016 and 2017.

Table 1. Literature review.

\begin{tabular}{ccccc}
\hline Author(s) & Year & Article & Journal & Summary \\
\hline Bailey \& Fernando [36] & 2017 & $\begin{array}{c}\text { Routine and project-based leisure, } \\
\text { happiness and meaning in life }\end{array}$ & Journal of Leisure Research & $\begin{array}{c}\text { Leisure activities (outdoor) } \\
\text { contribute to happiness }\end{array}$ \\
\hline Bailey, Kang \& Schmidt [37] & 2017 & $\begin{array}{c}\text { Leisure routine and positive attitudes: } \\
\text { Age-graded comparisons of the path } \\
\text { to happiness }\end{array}$ & Journal of Leisure Research & $\begin{array}{c}\text { Leisure activities (routine) } \\
\text { contribute to happiness }\end{array}$ \\
\hline Bimonte \& Faralla [38] & 2014 & $\begin{array}{c}\text { Happiness and } \\
\text { nature-based vacations }\end{array}$ & Annals of Tourism Research & $\begin{array}{c}\text { Nature contributes to tourists' } \\
\text { well-being }\end{array}$ \\
\hline Bimonte \& Faralla [39] & 2012 & $\begin{array}{c}\text { Tourist types and happiness } \\
\text { a comparative study in } \\
\text { Maremma, Italy }\end{array}$ & Annals of Tourism Research & $\begin{array}{c}\text { Type of vacation impacts on } \\
\text { tourists' happiness }\end{array}$ \\
\hline
\end{tabular}


Table 1. Cont.

\begin{tabular}{|c|c|c|c|c|}
\hline Author(s) & Year & Article & Journal & Summary \\
\hline Bimonte \& Faralla [11] & 2016 & $\begin{array}{c}\text { Does residents' perceived life } \\
\text { satisfaction vary with tourist season? } \\
\text { A two-step survey in } \\
\text { Mediterranean destination }\end{array}$ & Tourism Management & $\begin{array}{l}\text { Life satisfaction of residents } \\
\text { vary with tourist season }\end{array}$ \\
\hline Bimonte \&Faralla [40] & 2015 & $\begin{array}{l}\text { Happiness and outdoor vacations } \\
\text { appreciative versus } \\
\text { consumptive tourists }\end{array}$ & Journal of Travel Research & $\begin{array}{l}\text { Tourists involved in more } \\
\text { appreciative activities are } \\
\text { more concerned about the } \\
\text { environment and are happier }\end{array}$ \\
\hline Chen \& Li [41] & 2018 & $\begin{array}{c}\text { Does a happy destination bring you } \\
\text { happiness? Evidence from series from } \\
\text { Swiss inbound tourism }\end{array}$ & Tourism Management & $\begin{array}{l}\text { Tourist satisfaction has an } \\
\text { effect on tourist happiness }\end{array}$ \\
\hline Chia \& Chu [42] & 2016 & $\begin{array}{l}\text { Moderating effects of presentism on } \\
\text { the stress-happiness relationship of } \\
\text { hotel employees: A note }\end{array}$ & $\begin{array}{l}\text { International Journal of } \\
\text { Hospitality Management }\end{array}$ & Employees' happiness \\
\hline $\begin{array}{c}\text { Croes, Ridderstaat, Van Van } \\
\text { Niekerk [14] }\end{array}$ & 2018 & $\begin{array}{c}\text { Connecting quality of life, tourism } \\
\text { specialisation and economic growth } \\
\text { in small island destinations: The case } \\
\text { of Malta }\end{array}$ & Tourism Management & $\begin{array}{l}\text { Tourism specialisation } \\
\text { improves the residents QOL } \\
\text { but only on the short term }\end{array}$ \\
\hline $\begin{array}{l}\text { Gholipour, Tjajaddini \& } \\
\text { Nguyen [43] }\end{array}$ & 2016 & Happiness and inbound tourism & Annals of Tourism Research & $\begin{array}{c}\text { The level of happiness of the } \\
\text { locals contribute to } \\
\text { attract visitors }\end{array}$ \\
\hline Gillet, Schmitz \& Mitas [44] & 2013 & $\begin{array}{l}\text { The snap-happy tourist. The effects of } \\
\text { photographing behaviour on } \\
\text { tourists' happiness }\end{array}$ & $\begin{array}{l}\text { Journal of Hosp } \\
\text { Tourism Research }\end{array}$ & $\begin{array}{c}\text { There is a correlation between } \\
\text { the level of tourists' happiness } \\
\text { and photography }\end{array}$ \\
\hline $\begin{array}{l}\text { Hsiao, Jaw, Huan } \\
\& \text { Woodside [45] }\end{array}$ & 2015 & $\begin{array}{l}\text { Applying complexity theory to solve } \\
\text { hospitality contrarian case } \\
\text { conundrums: Illuminating happy-low } \\
\text { and unhappy-high performing } \\
\text { frontline service employees }\end{array}$ & $\begin{array}{l}\text { International Journal of } \\
\text { Contemporary } \\
\text { Hospitality Management, }\end{array}$ & $\begin{array}{l}\text { Model to evaluation of } \\
\text { employees' happiness }\end{array}$ \\
\hline Ivlevs [7] & 2017 & $\begin{array}{c}\text { Happy hosts? International tourists' } \\
\text { arrivals and residents' subjective } \\
\text { well-being in Europe }\end{array}$ & Journal of Travel Research & $\begin{array}{c}\text { Tourist arrivals impact } \\
\text { negatively residents' } \\
\text { life satisfaction }\end{array}$ \\
\hline $\begin{array}{l}\text { Khalizadeth, Ghahramani } \\
\text { \& Tabari [46] }\end{array}$ & 2017 & $\begin{array}{l}\text { From 'hypercritics' to 'happy } \\
\text { campers': Who complains the most in } \\
\text { fine dining restaurants? }\end{array}$ & $\begin{array}{c}\text { Journal Hosp } \\
\text { Marketing Management }\end{array}$ & $\begin{array}{l}\text { Happy customers are unlikely } \\
\text { to complain }\end{array}$ \\
\hline Kruger, Saayman \& Ellis [47] & 2014 & $\begin{array}{c}\text { The influence of travel motives on } \\
\text { visitor happiness attending } \\
\text { a wedding expo }\end{array}$ & $\begin{array}{l}\text { Journal of Travel } \\
\text { Tourism Marketing }\end{array}$ & $\begin{array}{c}\text { Attribute of wedding expo } \\
\text { contribute to enhance visitors } \\
\text { happiness QOL }\end{array}$ \\
\hline Lyu, Mao \& Hu [48] & 2018 & $\begin{array}{c}\text { Cruise experience and its contribution } \\
\text { to subjective well-being: A case of } \\
\text { Chinese tourists }\end{array}$ & $\begin{array}{l}\text { International Journal of } \\
\text { Tourism Research }\end{array}$ & $\begin{array}{l}\text { Holidays contributes to } \\
\text { subjective well-being }\end{array}$ \\
\hline Mcabe, Joldersmna \& Li [20] & 2010 & $\begin{array}{l}\text { Understanding the benefits of social } \\
\text { tourism: Linking participation to } \\
\text { subjective well-being and quality of life }\end{array}$ & $\begin{array}{l}\text { International Journal of } \\
\text { Tourism Research }\end{array}$ & $\begin{array}{l}\text { Holidays contribute to the } \\
\text { increase in QOL of } \\
\text { low-income families }\end{array}$ \\
\hline McCabe \& Johnson [49] & 2013 & $\begin{array}{l}\text { The happiness factor in tourism: } \\
\text { Subjective well-being and } \\
\text { social tourism }\end{array}$ & Annals of Tourism Research & $\begin{array}{l}\text { Tourism contributes to social } \\
\text { tourist's well-being }\end{array}$ \\
\hline Nawjin [50] & 2010 & $\begin{array}{l}\text { The holidays curve: A preliminary } \\
\text { investigation into mood during } \\
\text { a holiday abroad }\end{array}$ & $\begin{array}{l}\text { International Journal of } \\
\text { Tourism Research }\end{array}$ & $\begin{array}{l}\text { Level of happiness of tourists } \\
\text { fluctuates during holidays }\end{array}$ \\
\hline Nawjin [51] & 2011 & $\begin{array}{l}\text { Determinants of daily happiness } \\
\text { on vacation }\end{array}$ & Journal of Travel Research & $\begin{array}{l}\text { Tourism industry as a whole } \\
\text { contribute to people } \\
\text { happiness despite the fact } \\
\text { there is room for improvement }\end{array}$ \\
\hline Ram, Nawjin \& Peeters [52] & 2013 & $\begin{array}{l}\text { Happiness and limits to sustainable } \\
\text { tourism mobility: A new } \\
\text { conceptual model }\end{array}$ & $\begin{array}{c}\text { Journal of } \\
\text { Sustainable Tourism }\end{array}$ & $\begin{array}{c}\text { Happy tourists in life are more } \\
\text { likely to have sustainable } \\
\text { attitude when travelling }\end{array}$ \\
\hline Spiers \& Walker [53] & 2008 & $\begin{array}{c}\text { The effects of ethnicity and leisure } \\
\text { satisfaction on happiness, } \\
\text { peacefulness and quality of life }\end{array}$ & Leisure Sciences & $\begin{array}{l}\text { There is a link between } \\
\text { ethnicity and happiness }\end{array}$ \\
\hline $\begin{array}{l}\text { Theodorakis, Kaplanidou } \\
\text { \& Karabaxoglou [54] }\end{array}$ & 2015 & $\begin{array}{l}\text { Effect of event service quality and } \\
\text { satisfaction on happiness among } \\
\text { runners of a recurring sport event }\end{array}$ & Leisure Sciences & $\begin{array}{l}\text { Events positively impact on } \\
\text { the satisfaction of participants }\end{array}$ \\
\hline Tsaur, Yen \& Hsaio [55] & 2012 & $\begin{array}{l}\text { Transcendent experience, flow and } \\
\text { happiness for mountain climbers }\end{array}$ & $\begin{array}{l}\text { International Journal of } \\
\text { Tourism Research }\end{array}$ & $\begin{array}{l}\text { Mountain climbing contribute } \\
\text { to tourists' well-being }\end{array}$ \\
\hline Walker \& Ito [56] & 2017 & $\begin{array}{l}\text { Mainland Chinese Canadian } \\
\text { immigrants' leisure satisfaction and } \\
\text { subjective well-being: results of } \\
\text { a two-year longitudinal study }\end{array}$ & Leisure Sciences & $\begin{array}{l}\text { Leisure satisfaction positively } \\
\text { affect happiness and } \\
\text { satisfaction of life }\end{array}$ \\
\hline $\begin{array}{l}\text { Wei, Huang, } \\
\text { Stodolska \& Yu [57] }\end{array}$ & 2017 & $\begin{array}{c}\text { Leisure time, leisure activities and } \\
\text { happiness in China }\end{array}$ & Journal of Leisure Research & $\begin{array}{c}\text { Leisure activities contribute to } \\
\text { happiness }\end{array}$ \\
\hline
\end{tabular}




\section{Methodology}

\subsection{Background}

The present research is partly inspired by a study carried out by researchers from the Rosen College of Hospitality Management at the University of Central Florida, on the perception of happiness and satisfaction with life in Aruba carried out in 2016 to update the previous survey carried out in 2011 as part of a master plan called 'Winning the Future'. This study was chosen because it is quite up to date but also because Aruba and Winchester have a key common point. Indeed, the study revealed that Aruba may be considered as the 'happiest destination on the planet' [8] and Winchester is considered as a good place to live in the UK, according to a BBC report (www.bbc.com/news/uk-england-38351138, last access 30 September 2018). The level of happiness in Aruba is to be attributed to time perspective (or opportunities to celebrate local achievements) and optimism (as a thinking style). Croes et al. [8] also explained that social channel initiative is important in sustaining internal happiness in Aruba. Moreover, the study also revealed that tourism (jobs, income, business opportunities, etc.) is serving a lesser role in residents' overall happiness. As for Winchester, the research explains that the results of the plebiscite were due to the fact that the city has some of the lowest crime rates in the country and the life expectancy, the level of health, were quite high compared to the rest of the country. Tourism (and/or events) were not taken into consideration in this survey.

This research paper could also be placed as complementary of three existing pieces of research: (a) Uysal et al. [12] who established through conceptual research the existence of a link between tourism and tourists' and residents' overall satisfaction with life and well-being. (b) Ivlevs [7], research based on secondary data (using data from the European Social Survey) evidenced that tourism arrival impacts on local residents' life satisfaction. Finally, (c) Bimonte and Faralla [11], as our research gives results but from the point of view of a SITE destination (and not from a mass tourism perspective). On the other hand, Ivlevs [7] and Bimonte and Faralla [11] encouraging further studies to have the perspective from different residents and draw more reliable conclusions and help towards the consensus regarding the impact of tourism on the well-being of locals.

\subsection{Contextual Framework: Winchester}

The survey was carried out in Winchester (Hampshire, UK) and its wards (Figure 1), a city surrounded by some of the most visited UK destinations, namely London, Oxford and Cambridge.

Results from the 2011 Census show that Winchester's population is 116,600. This is an increase of 9380 from the 2001 census figure of 107,220 . In percentage, this is an $8.7 \%$ increase, which is slightly higher than the $7.1 \%$ figure for the whole of England and Wales. The total number of households has increased by 3762 (also $8.7 \%$ ) from 43,138 to 46,900 . The wards with the largest population increases are Whiteley and Wickham with a respective $1034 \%$ and $1689 \%$ (www.winchester.gov.uk/ data).

Winchester has low levels of unemployment. Indeed, it is one of the $20 \%$ least deprived districts/unitary authorities in England. According to Public Health England, the health of people in Winchester is generally better than the England average. Life expectancy for both men and women is higher than the England average. People in Winchester scored 7.7 out of 10 in the happiness charts compiled by the Office of National Statistics, against a national average of 7.4. They also scored 7.9/10 for life satisfaction (national average 7.5); 8/10 for feeling worthwhile (national average 7.8) and 2.7/10 for anxiety (national average 2.9). 

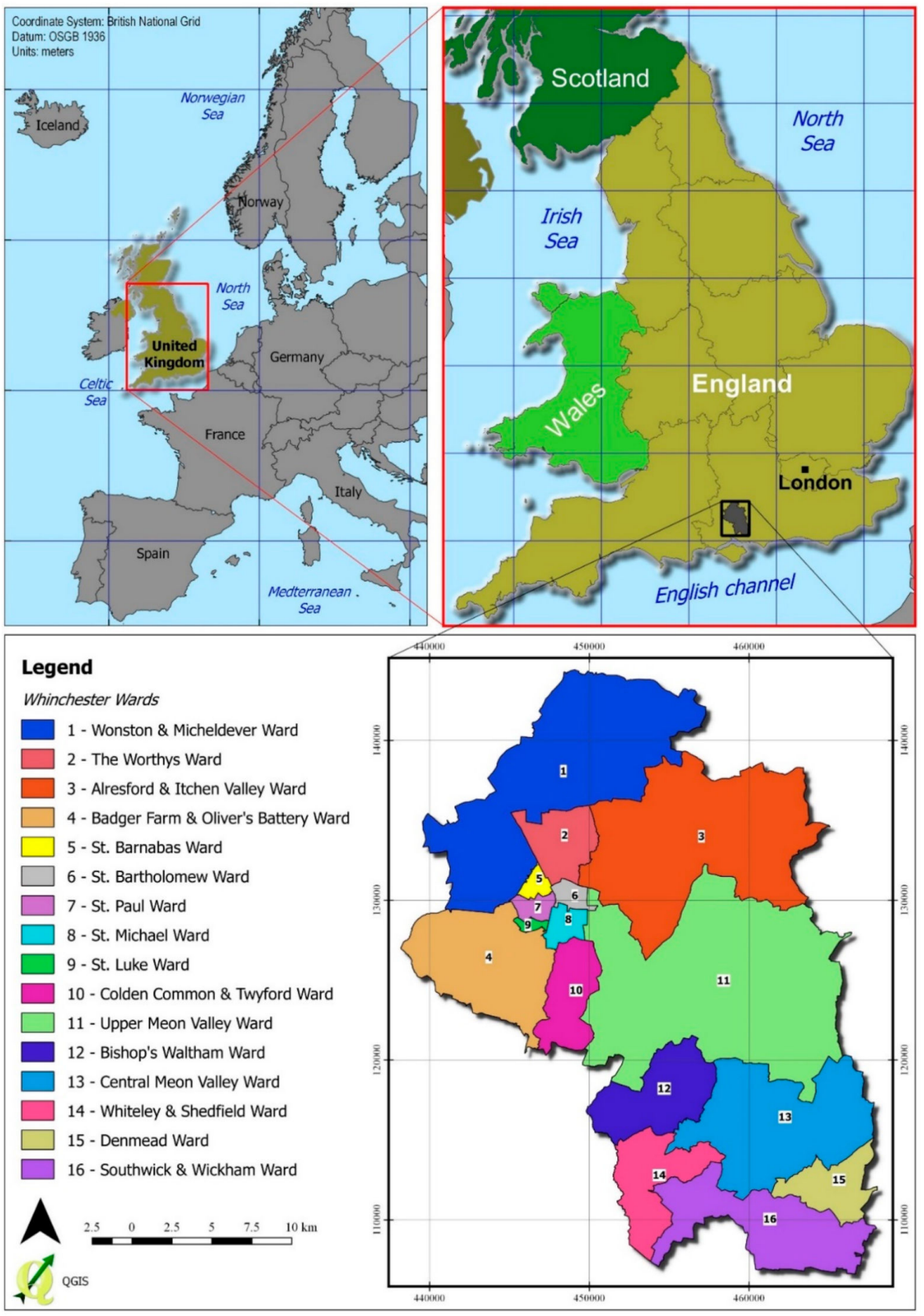

Figure 1. Geographical location of Winchester (UK) and its wards (elaboration by the Authors, boundaries provided as open data products by Ordnance Survey UK-CC Crown copyright and database right 2018).

Winchester is also an eventful city with a range of events and festivals all year round (Table 2). The events organised fall under music and comedy events (10); art and literature events (10); children (6) and food and drink events (7). Many of the event organisers in the city communicate with one another and are part of the 'Festivals in Winchester Group' which is chaired by Winchester Business Improvement District (BID), a business-funded and business-led organisation and supported by Visit Winchester (the local Destination Marketing Organisation). The 'Festivals in Winchester Group' brings event organisers together to encourage discussion and collaboration, delivers an annual marketing campaign for the city's events and festivals and aims to coordinate a diverse programme throughout the year. 
Table 2. Community Based Festivals in Winchester (UK).

\begin{tabular}{|c|c|c|c|c|c|c|c|c|c|c|c|}
\hline Jan & Feb & March & April & May & June & July & Aug & Sept & Oct & Nov & $\overline{\text { Dec }}$ \\
\hline & $\begin{array}{c}\text { Children of } \\
\text { Winchester } \\
\text { Festival }\end{array}$ & $\begin{array}{l}\text { Winchester } \\
\text { Beer } \\
\text { Festival }\end{array}$ & $\begin{array}{c}\text { Easter } \\
\text { Bunny Hop }\end{array}$ & $\begin{array}{l}\text { Winchester } \\
\text { Mayfest }\end{array}$ & $\begin{array}{l}\text { Winchester } \\
\text { Speakers } \\
\text { Festival }\end{array}$ & $\begin{array}{l}\text { Winchester } \\
\text { Festival }\end{array}$ & Boomtown & $\begin{array}{c}\text { SC4M } \\
\text { Americana } \\
\text { Music } \\
\text { Festival }\end{array}$ & $\begin{array}{c}\text { Harvest } \\
\text { Weekend }\end{array}$ & $\begin{array}{l}\text { Bonfire and } \\
\text { Fireworks }\end{array}$ & $\begin{array}{l}\text { Woolly } \\
\text { Hat Fair }\end{array}$ \\
\hline & & & $\begin{array}{l}\text { Winchester } \\
\text { Fashion } \\
\text { Week }\end{array}$ & & $\begin{array}{l}\text { Ginchester } \\
\text { Fete }\end{array}$ & $\begin{array}{c}\text { Hampshire } \\
\text { Food } \\
\text { Festival } \\
\end{array}$ & $\begin{array}{l}\text { Cheese \& } \\
\text { Chilli } \\
\text { Festival }\end{array}$ & $\begin{array}{c}\text { Winchester } \\
\text { Community } \\
\text { Games }\end{array}$ & $\begin{array}{c}\text { Winchester } \\
\text { Comedy } \\
\text { Festival } \\
\end{array}$ & $\begin{array}{c}\text { Winchester } \\
\text { Short Film } \\
\text { Festival }\end{array}$ & \\
\hline & & & $\begin{array}{l}\text { Winchester } \\
\text { Chamber } \\
\text { Music } \\
\text { Festival }\end{array}$ & & $\begin{array}{l}\text { Winchester } \\
\text { Criterium } \\
\text { and } \\
\text { Cyclefest }\end{array}$ & $\begin{array}{l}\text { Southern } \\
\text { Cathedrals } \\
\text { Festival }\end{array}$ & $\begin{array}{l}\text { Graze } \\
\text { Festival }\end{array}$ & $\begin{array}{c}\text { Winchester } \\
\text { Jazz } \\
\text { Festival }\end{array}$ & $\begin{array}{l}\text { Winchester } \\
\text { Poetry } \\
\text { Festival }\end{array}$ & $\begin{array}{l}\text { Winchester } \\
\text { Christmas } \\
\text { Light } \\
\text { Switch On }\end{array}$ & \\
\hline & & & & & $\begin{array}{l}\text { Winchester } \\
\text { Writers' } \\
\text { Festival }\end{array}$ & $\begin{array}{l}\text { Winchester } \\
\text { Science } \\
\text { Festival } \\
\text { (Winscifest) }\end{array}$ & & & & $\begin{array}{l}\text { Christmas } \\
\text { Market and } \\
\text { Ice Rink }\end{array}$ & $\begin{array}{l}\text { Christmas } \\
\text { Market and } \\
\text { Ice Rink }\end{array}$ \\
\hline & & & & & $\begin{array}{l}\text { Winchester } \\
\text { School } \\
\text { of Art } \\
\text { Degree Show }\end{array}$ & & & & & $\begin{array}{c}\text { Wine } \\
\text { Festival } \\
\text { Winchester }\end{array}$ & \\
\hline & & & & & $\begin{array}{l}\text { Winchestival } \\
\text { Hat Fair }\end{array}$ & & & & & & \\
\hline & & & & $\begin{array}{c}\text { Musi } \\
\text { Art \& }\end{array}$ & $\begin{array}{l}\text { shion event } \\
\& \text { comedy eve } \\
\text { literature even } \\
\text { port events }\end{array}$ & & $\begin{array}{r}\text { Science ev } \\
\text { Children e } \\
\text { Food \& drink }\end{array}$ & $\begin{array}{l}\text { nts } \\
\text { ents } \\
\text { events }\end{array}$ & & & \\
\hline
\end{tabular}

Source: The authors. 
In 2010, Winchester was visited by 4.3 million day trippers. In 2015 (the latest data available), they were 5.4 million generating an additional $£ 199$ million in visitor trip expenditure ( $w w w$.winchester. gov.uk/data/tourism-data; http:/ / www.tourismsoutheast.com).

\subsection{Winchester: A Special Interest Tourism and Events (SITE) Destination}

According to Hall and Weiler [58], Special Interest Tourism (SIT) occurs 'when the travellers' motivation and decision-making are primarily determined by a particular special interest with a focus either on activity/ies and/or destinations and settings'. SIT appeared to accommodate the varied and specialised needs and tastes of tourists and is to be opposed to mass consumption and non-commercialised individual travel [59,60]. This form of tourism emerged in the 1980s [59] and was stimulated by a need for cultural and environmental holidays [28]. SIT contributes to enhance the image of a destination; to enrich tourists' experiences and is profitable to a wider range of providers [61]. Other terms used alongside SIT are: alternative, sustainable, appropriate, new, responsible, eco, niche and responsible and ego tourism [59,61].

Heritage tourism as a niche market is to be assimilated to SIT and, according to Park [60] and Seraphin et al. [6], 'heritage' is built around three constructs: scientific heritage (natural features/ geographical features/plants/birds/natural habitats/etc.), cultural heritage (quality of life/authenticity of experience/history/customs/languages/etc.) and built heritage. On that basis, it could be argued that traditional events attended by tourists are to be considered as Special Interest Event (SIE), a view also supported by Yeoman et al. [28]). These events can generate intense publicity and awareness, enrich the QOL of local people and attract tourists from outside the area [62,63]. Moreover, SIEs contribute in maintaining and enhancing local community cohesion and identities [60], engendering pride in the community; strengthening a feeling of belonging; creating a sense of place [64]; and create a cultural and social environment for tourists who are attending the event [63]. Findings of Trauer [59] imply that SIT contributes to people happiness as this form of tourism is a results of people desire for QOL. By the way, according to Park [60], there is the need to involve local communities since the early stages of these events to reach all these goals.

SIT does have some limitations due to the fact it is quite niche, therefore very sensitive to changes. It is all the more the case for destinations with a SIT based on natural features like niche market such as diving and so forth. [65]. The heritage features of the destination contribute to the aesthetic of the destination. The aesthetic characteristics of a destination contribute to: The experience and satisfaction of visitors and to their loyalty [66]. All in all, we can argue that heritage tourism and events as forms of SITE contribute to the happiness of locals and visitors. The survey (questionnaire) will confirm or not our findings (based at the moment only on secondary research).

\subsection{Survey}

The questionnaire was developed based on the results of previous studies on residents' support and perceived impacts regarding tourism development. Statements from the existing literature were adopted to enhance reliability and validity of the questionnaire.

This questionnaire (Table A1) has three main sections. The first provide a measurement of the wellbeing dimension (11 variables), composed in three domains that are satisfaction (quality of life), time perspective (subjective manner we relate to time) and optimism (expectation that something good will happen in the future).

The second section is an assessment of the contributions of tourism to community well-being based on four community well-being domains, as measured by a 5-point scale, ranging from 1 (completely disagree) to 5 (completely agree) (14 items);

Finally, the last section devoted to evaluating residents' attitude to tourism and events and the connection with their life satisfaction ( 15 items, from 1 to 5 ). We also measured this section on a 5-point scale. As for the domains in the second section, these are related to wellbeing linked to tourism perception (dynamic process that integrates place, people and mobility). 
The questionnaire also had a short section (right at the beginning) aimed at recording the socio-demographic details of residents (where they live; their age; gender; number of children; and their occupation).

In terms of number of responses that would make the results reliable, Bimonte and Faralla [11] used a sample of 225 individuals for a destination (Follonica, Italy) of 21,500 residents, what equates to $1 \%$ of the population. Uysal et al. [12] used 407 respondents while Kim et al. [9] 321 respondents and Nawijn and Mitas [51] 373 respondents. On that basis, we have decided that a reasonable sample for our study should be between 225 respondents and 1160 respondents ( $1 \%$ of the population of Winchester).

The questionnaire was designed on Google Forms (www.google.com/forms). As for data, they were collected online between the month of January and March 2018. The survey link was posted on a variety of platforms:

- Facebook Groups (We Are Winchester; Winchester Rants; Winchester Pics; Winchester Bloggers; etc.)

- LinkedIn

- Twitter (Winchester Business Improvement District [BID], Festivals in Winchester, Visit Winchester, Winchester City Council)

- Winchester (BID) newsletter

- Alumni mailing list for the University of Winchester

The questionnaire only targeted 18+ living in Winchester municipality. Altogether 396 respondents took part to the survey, with 308 valid questionnaires.

\subsection{Data Analysis}

With regard to data processing, a mixed technique was used [67-72]. Firstly, factor analysis (FA) was used to summarise the information in tourism impact perception into a smaller set of new dimensions. Subsequently, segments of tourism perception were defined using cluster analysis (CA) applied to the factor scores. Finally, ordinal regression analysis was conducted for wellbeing and tourism events held in Winchester. To have a comprehensive overview at the geographical location of respondents to the questionnaire, we map them by means of a Geographic Information System (GIS) according to the sixteen Winchester wards' boundaries as geographical reference units (www.winchester.gov.uk/elections/ward-map, last access 14 June 2018) (Figure 1). Geographical data were freely downloaded from the UK Data Service database (www.ukdataservice.ac.uk/get-data, last access 12 September 2018) in the coordinate reference system OSGB 1936/British National Grid (EPSG code 27700). All maps were produced using the free and open source software QGIS (ver. 2.18, Las Palmas, Spain). We also mapped the gender composition of respondents.

\section{Results}

\subsection{Brief Overview}

The results of this analysis are based on 308 (valid) responses. Most of the people who respondent to the survey $(60 \%)$ are from the five wards of Winchester city centre. It is also worth mentioning the fact no one from the wards of Southwick \& Wickham and Denmead (Figure 2-number 16) took part in the survey, what represents a (minor) limitation to the results of the survey. Table 3, provides more detailed information on the respondents. 
Table 3. Key characteristics of the respondents to the survey.

\begin{tabular}{ccc}
\hline Characteristics & Frequency & Percent \\
\hline Gender & 244 & 79.2 \\
Female & 64 & 20.8 \\
Male & & \\
Age & 83 & 26.9 \\
Gen z & 151 & 49.0 \\
Gen $x$ & 74 & 24.0 \\
Baby boomers & 196 & 63.6 \\
\hline Respondents with children & & \\
\hline Activity & 206 & 66.9 \\
Employed & 26 & 8.4 \\
Homemaker & 20 & 6.5 \\
Other & 31 & 10.1 \\
Retired & 22 & 7.1 \\
Student & 3 & 1.0 \\
Unemployed & &
\end{tabular}

Source: The authors.

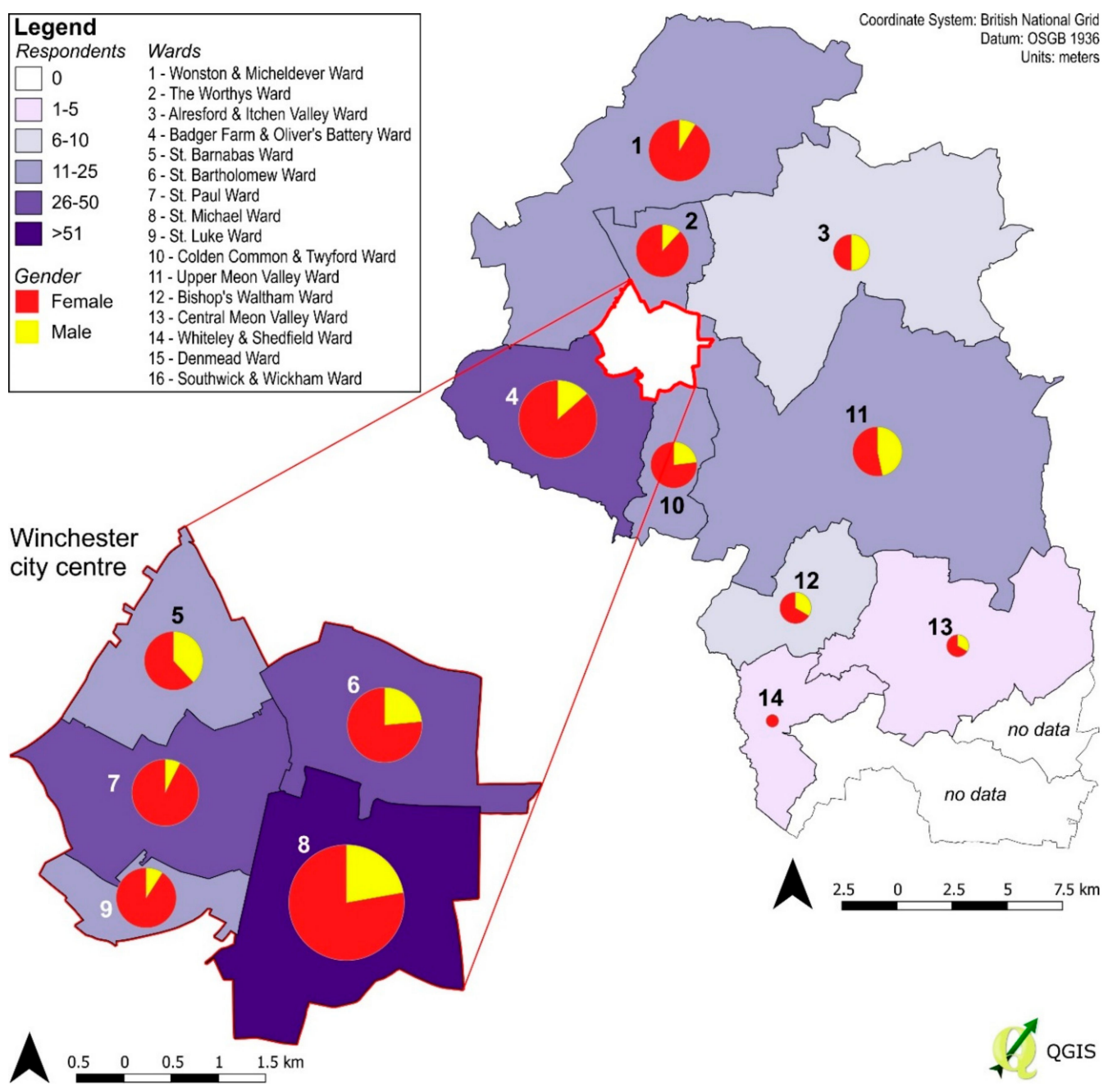

Figure 2. Respondents (number \& gender) to the survey and their geographical locations (elaboration by the Authors, boundaries provided as open data products by Ordnance Survey UK-C Crown copyright and database right 2018). 


\subsection{Link between Tourism and the Level of Happiness of Residents}

The 14 measurement items related to tourism perception were subject to FA which identified the constructs that underlie a dataset based on the correlations between variables. We used traditional procedures to identify common factors. After verifying the statistical significance of the data with KMO (with value 0.89 ) and Bartlett's test of sphericity $(2,319,792)$, the factors were drawn from the correlation matrix using principal components analysis. The criteria for determining the number of factors are an eigenvalue greater than 1 and scree plots. The four components identified with these methods were unclear and not univocally described. Therefore, we applied orthogonal rotation using the Varimax method, which made the matrix of extracted components easier to read. The four components extracted accounted for $72 \%$ of the overall variance (Table 4 ).

Table 4. Rotated component matrix.

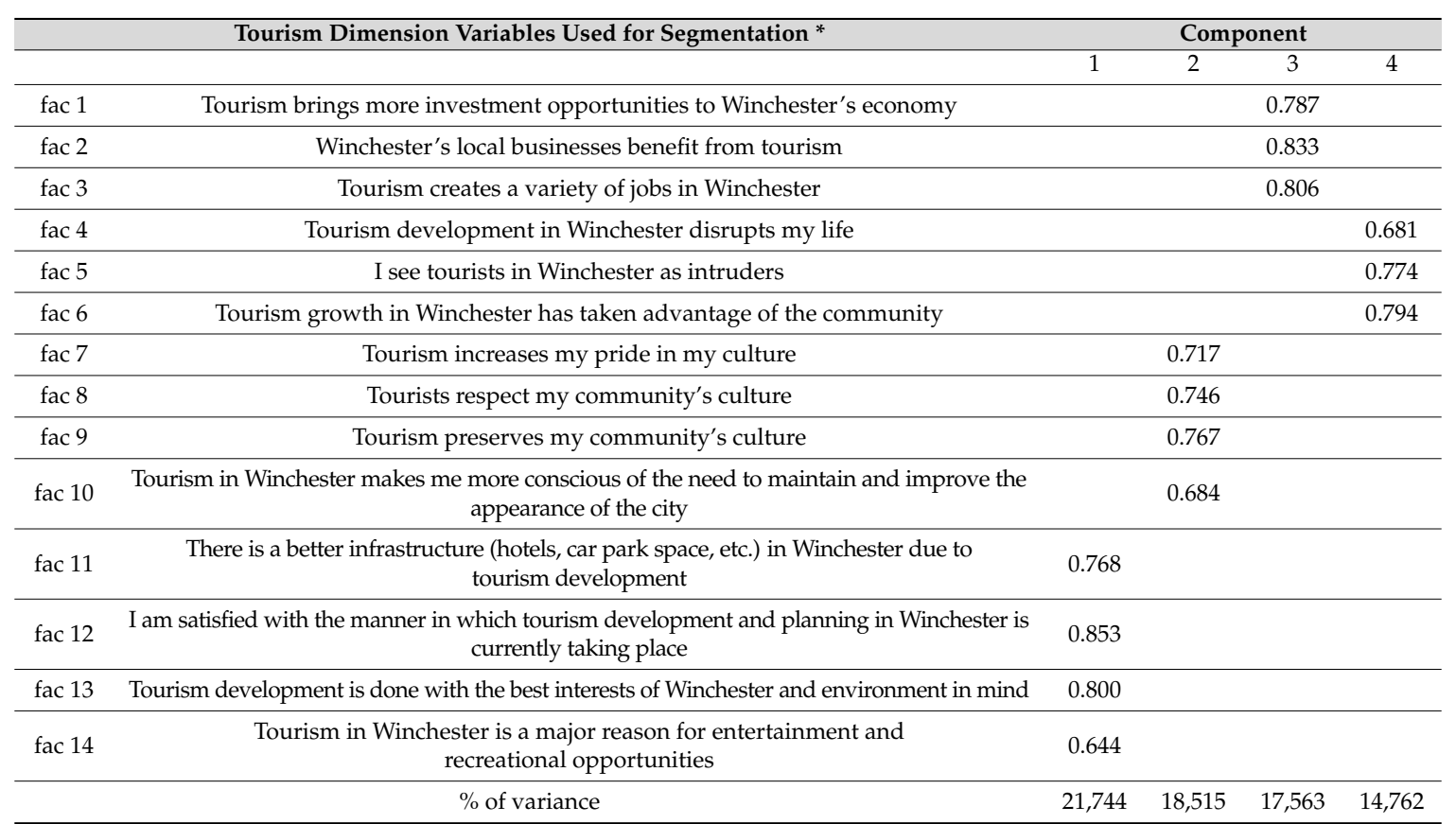

Source: The authors. KMO-MSA $=0.89$; Bartlett's test of sphericity $=2,319,792$. Extraction Method: Principal

Component Analysis. Rotation Method: Varimax with Kaiser normalization. $\left(^{*}\right)$ scale used: $1=$ never; $5=$ always.

The first factor groups the variables related to the positive effects that tourism brings to Winchester. In fact, it brings together the variables related to the better infrastructure due to tourism development (fac 11), the satisfaction for the tourism development in Winchester (fac 12), the relation between tourism development and interest in Winchester (fac 13) and finally the entertainment and recreational opportunities for Winchester that born thanks to tourism (fac 14). This factor counts the $21.7 \%$ of the variance extracted. We call this dimension "Tourism supporters".

The second factor groups the variables related to the link between tourism and culture ("tourism and culture" dimension). We found that the components (that represents $18.5 \%$ of the variance extracted) brings together the variables of importance of tourism for community culture (fac 8 and fac 9), the relation between tourism and pride for culture (fac 7) and importance of tourism in Winchester to maintain and improve the appearance of the city (fac 10).

The third factor counts $17.5 \%$ of the variance extracted and groups three variables that are the presence of investments with tourism development (fac 1), Winchester's local businesses benefit from tourism (fac 2 ) and the variety of jobs in Winchester that will born with tourism (fac 3 ). We call this component the "tourism and outputs" dimension.

The last factor ( $14.7 \%$ of the variance extracted), the fourth, represents the components perceived as negative impact of tourism. The variables grouped are ones which link tourism development to 
negative impacts on one's own life (fac 4) and to the negative presence of tourists, meaning as intruders (fac 5). The last variable does not appear related to the negative impact of tourism. The description is "Tourism growth in Winchester has taken advantage of the community": probably the respondents have perceived the advantages not for all the community but only for a part of the whole community. This component is the "tourismphobia" dimension.

Using factor scores, a CA was developed to group the respondents on the basis of their perception of tourism impact. The grouping procedure has been provided by different steps: first of all, the correlations are checked since variables that are highly correlated are liable to distort the results. To detect the number of the groups we use firstly a hierarchical Cluster. The optimal cluster solution was determined by analysing changes in agglomeration coefficients. Secondly, a direct classification algorithm (non-hierarchical) around mobile centres (K-Means algorithm) has been applied, using the statistical package SPSS. This combined procedure has benefit from the advantages associated with hierarchical and non-hierarchical methods, while at the same time minimizing the drawbacks (Landau \& Everitt, 2004; Punj \& Stewart, 1983).

The cluster analysis applied to the four components extracted identifies four different clusters. For an intuitive comprehension of the four cluster meanings, the components extracted media value of the clusters was plotted (Figure 3). The higher the value of the average, the greater the strength of the link to the extracted dimension.

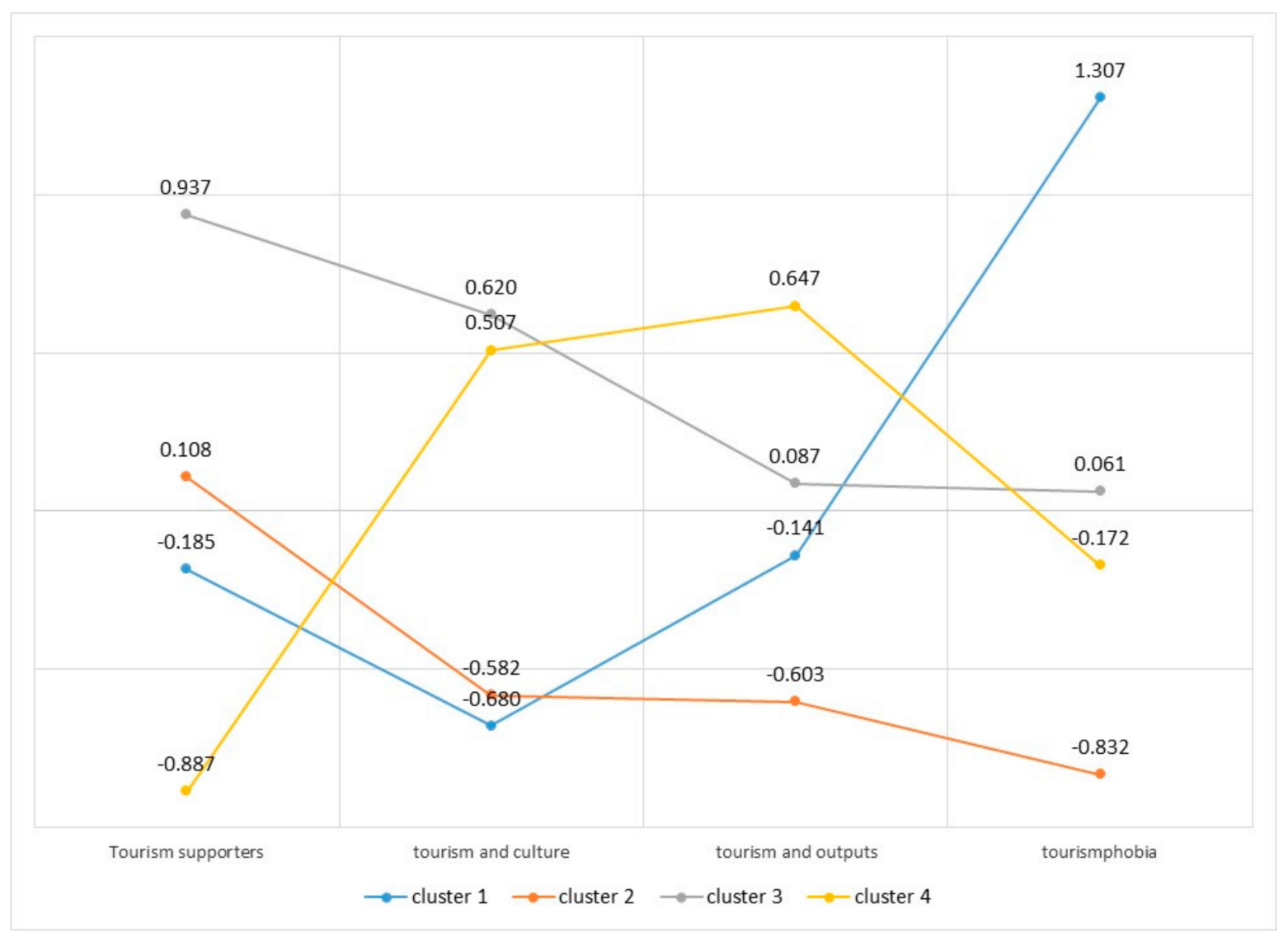

Figure 3. Comparison of the four clusters (average value). Source: The authors.

The interpretation of the first cluster is very easy. This is a group of respondents who fear the negative effects brought by tourism (the cluster has a very high average value of factor scores for the fourth component extracted "tourismphobia"). In this sense, the low value of the second component (the cultural dimension) is also understandable. The second cluster is characterized above all by its lower value compared to the fourth component extracted. They are respondents who, contrary to the first cluster, are not afraid of tourism. The cluster shows negative value for all the dimensions, with the 
exception of the first component (tourism supporters). The respondents of this cluster have showed a low involvement in the analyses of the tourism effects on Winchester.

The third cluster is the one that presents the strongest link with the "tourism supporters" dimension. The fourth cluster is linked to the "tourism and outputs" dimension.

For a clearer understanding of the relationship between clusters and the dimension of the well-being (satisfaction, time perspective, optimism), let us now consider the differences in mean values of questionnaire responses. Practically, we take into consideration the question of the section "wellbeing dimension" (see Table A1-Appendix A) and calculate the frequencies of the responses for each cluster. For each sentence, the respondents should have expressed their degree of agreement (from 1 (completely disagree) to 5 (completely agree)). Except for sentences It 4 and It 5 , they are expressed in positive sense, so if the respondents declare high agreement, he/she shows an optimistic vision of the life. Vice versa for It 4 and It 5, which are in negative sense, the agreement showed a negative perception of the life.

Prevalence ratios (PR) were calculated between the average of a specific variable in the segment (a) and the average of the same value in the remaining sample (b) (PR $(c=a / b))($ Table 4). The PR shows clearly the characteristics of each clusters to respect the whole sample.

Looking to the clusters first (59 respondents, linked to "tourismphobia" dimension) and second (82 respondents: tourism supporters), we could see that they have PR values usually under the sample value for the optimistic items except for It 4 and It 5 . Differently, the others two clusters (linked to the "tourism and outputs" and "tourism supporters" dimension) have values always above the average sample values. It is evident the optimistic vision of the life that is expressed by the cluster three (77 respondents) and four (79 respondents)

The analyses of the clusters according the PR value is useful for the comprehension of the relationship between the different dimensions of the tourism (Table 4), which produce also their effects on community and the perception of the life of the subjects that compose the clusters. It interesting to note that the second cluster have an (average) value of the components extracted contrary to the dimension of tourismophobia (Figure 3) but in the same time, express a negative vision of life. (Table 5).

Table 5. Average of the population sample and prevalence ratios (PR) of the cluster $\left(^{*}\right)$.

\begin{tabular}{|c|c|c|c|c|c|c|}
\hline Item Code & Item Description & Sample ** & 1 Cluster $* * *$ & 2 Cluster $* * *$ & 3 Cluster $* * *$ & 4 Cluster $* * *$ \\
\hline It 1 & $\begin{array}{l}\text { If I could live my life over, I would } \\
\text { change nothing }\end{array}$ & 3.25 & 0.95 & 0.97 & 1.07 & 1.01 \\
\hline It 2 & $\begin{array}{l}\text { I can find the time to do most } \\
\text { everything I want to do }\end{array}$ & 3.31 & 1.08 & 0.95 & 1.01 & 1.01 \\
\hline It 3 & I laugh a lot & 3.92 & 0.99 & 0.96 & 1.03 & 1.01 \\
\hline It 4 & $\begin{array}{l}\text { I often think of what I should have } \\
\text { done differently in my life }\end{array}$ & 2.81 & 0.99 & 1.03 & 0.92 & 1.06 \\
\hline It 5 & $\begin{array}{l}\text { I think about the good things that I } \\
\text { have missed out on in my life }\end{array}$ & 2.34 & 1.10 & 1.03 & 0.96 & 0.94 \\
\hline It 6 & It gives me pleasure to think of my past & 3.62 & 1.01 & 0.91 & 1.06 & 1.04 \\
\hline It 7 & $\begin{array}{l}\text { I make decisions on the spur of } \\
\text { the moment }\end{array}$ & 3.14 & 0.99 & 0.97 & 1.04 & 1.03 \\
\hline It 8 & $\begin{array}{l}\text { It is important to put excitement in } \\
\text { my life }\end{array}$ & 3.92 & 0.97 & 0.99 & 1.04 & 1.00 \\
\hline It 9 & $\begin{array}{c}\text { In uncertain times, I usually expect } \\
\text { the best }\end{array}$ & 3.30 & 1.01 & 0.93 & 1.02 & 1.05 \\
\hline It 10 & I am always optimistic about my future & 3.66 & 0.98 & 0.92 & 1.04 & 1.06 \\
\hline It 11 & $\begin{array}{l}\text { Overall, I expect that more good things } \\
\text { will happen to me than bad things }\end{array}$ & 3.82 & 0.98 & 0.93 & 1.03 & 1.06 \\
\hline
\end{tabular}

Source: The authors. $\left({ }^{*}\right)$ Number of cases (respondents) for each cluster: 1 cluster $=59 ; 2$ cluster $=82 ; 3$ cluster $=77$; 4 cluster $=79 .\left({ }^{* *}\right)=\mu$. $\left({ }^{* * *}\right)=$ PR. 


\subsection{Link between the Level of Happiness of Residents and Events}

In the previous part of the analysis, the research has analysed the perception of tourism between Winchester's resident, seeking the dimensions more correlated with the wellbeing. Now, this results will be used in order to deepen the perception of the well-being of Winchester residents with respect to the tourist events realized in the city. Two elaboration will be presented, that is an analysis of the level of satisfaction of the clusters respect the events and, the second one, the relationship between residents' perception of the contribution of tourism events to the well-being and the dimension of tourism.

The first one shows the average level of satisfaction for each of the events by cluster and for the entire sample was analysed. The results are presented in Figure 4.

First of all, the average of the results expressed by the entire sample allows us to understand which events contribute most to the local community enjoyment of life. In the Figure 4 we see that the events related to Christmas, History, Food and Drink and Art are those with the highest average score. They are therefore considered as those that give the greatest contribution to the community well-being. The events with the lowest score are those of Fashion, Film and Literature.

If we consider the average cluster evaluations, we see that clusters 3 and 4 are always above the average evaluation of the entire sample. These clusters are those that have the strongest link with the "tourism supporters" factor (cluster 3) and with "tourism and outputs" (cluster 4). Cluster 1 instead shows the lowest average values compared to all clusters. This cluster is the most linked to the "tourismphobia" factor.

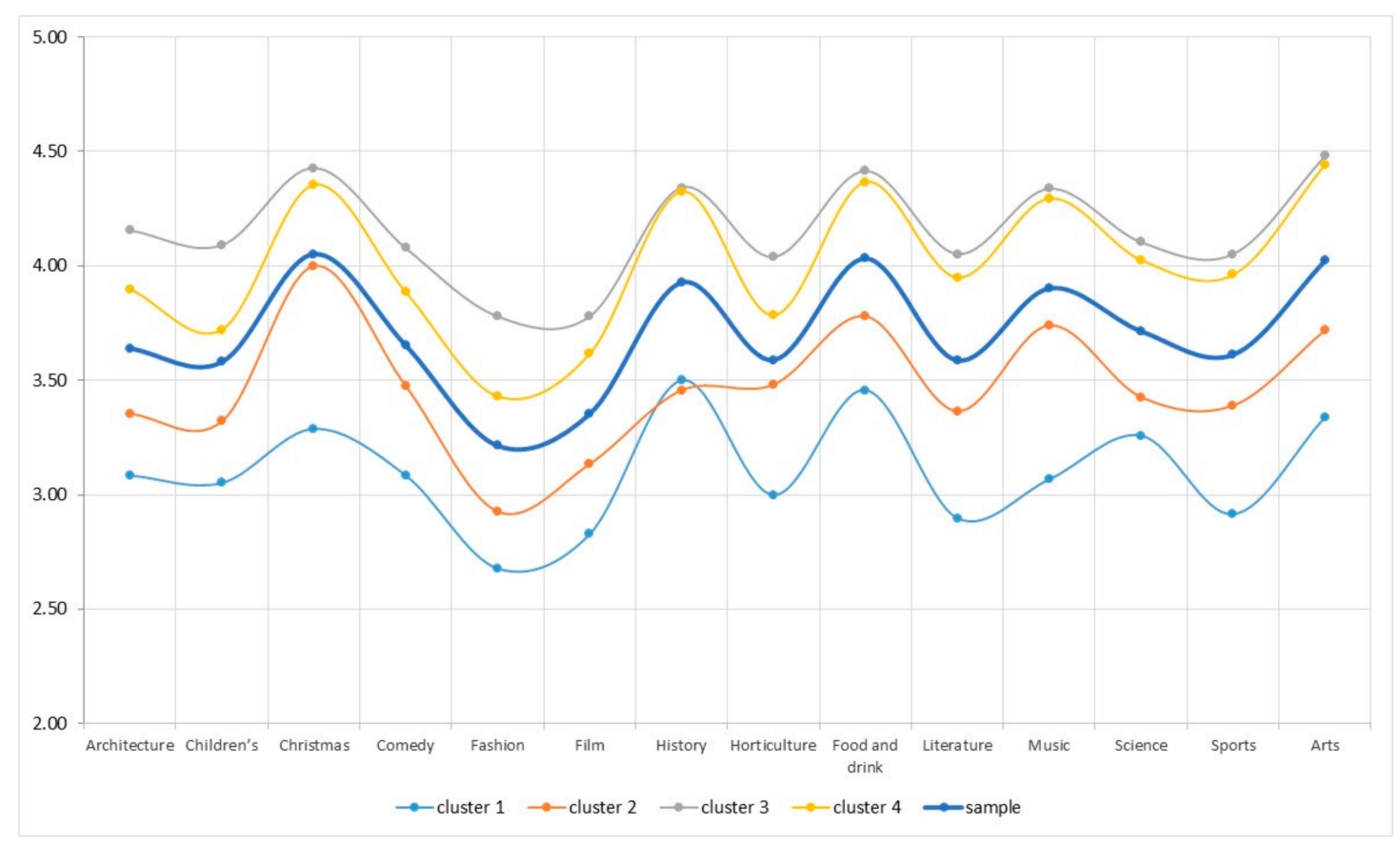

Figure 4. Average value of events satisfaction for entire sample and for each cluster. Source: The authors.

In the questionnaire, respondents were also asked to express an opinion on the influence of events on the wellbeing of the community (the item is: "Events development in Winchester is done with the best interests of the local community and environment." See in the section "tourism impact": Table A1-Appendix A). A regression analysis was conducted to identify the relative importance of the factors that influenced the residents' perception of the contribution of tourism to the well-being provided by the tourist events in Winchester. The well-being of the local community and the environment was used as a dependent variable and the four factors identified in the factor analysis (Tourism supporters, Tourism culture, Tourism and outputs, Tourismphobia) as independent variables. Because the dependent variable cannot be considered a continuous variable (it is measured in a five 
point Likert scale), an ordinal regression was estimated [73,74]. An ordinal regression is a more appropriate statistical procedure than a multiple linear regression, because the latter would obtain heteroscedastic and non-normal errors [75].

The results indicated that all the four factors are significant predictor (Table 6). Parameters $\beta$ show the effect of the explanatory variables on the logarithm of the probability ratio. A positive coefficient indicates a greater probability of a higher score for the dependent variable. The strongest predictive effect was observed for "tourism supporters" while "tourismphobia" has negatively affected the perception of the tourism events effects on well-being of the community.

Table 6. Ordinal regression results on the residents' perception of the contribution of tourist events to the well-being.

\begin{tabular}{cccccc}
\hline Factors & Estimation & Wald & Sig & Exp (B) & \% Variance in the Odds \\
\hline Tourism supporters & 1.630 & 125,322 & 0.000 & 5.101 & 410.1 \\
\hline Tourism culture & 0.945 & 58,446 & 0.000 & 2.572 & 157.2 \\
\hline Tourism and outputs & 0.694 & 33,838 & 0.000 & 2.003 & 100.3 \\
\hline Tourismphobia & 0.746 & 38,985 & 0.000 & 0.474 & -52.6 \\
\hline \multicolumn{6}{c}{ Cox and Snell: 0.546; Nagelkerke: 0.574 } \\
\hline \multicolumn{6}{c}{ Source: The authors. }
\end{tabular}

\section{Conclusions}

\subsection{Summary}

The research objectives introduced in the first part of the paper are related to the comprehension of the perception of the tourism sector among Winchester residents and the relationship between tourism and events impact on local residents' subjective well-being.

The local residents in Winchester perceive the tourism industry and events rather positively as they believe it supports their culture and the local economy and job in particular. The positive perception of tourism and events in Winchester is due to the profile of the local residents (as described in 'Contextual framework'-Section 3).

The Factor Analysis found four different dimensions that describe the relationship between tourism and wellbeing in Winchester. One of these dimensions is evidently connected to the fear of tourism (tourismphobia) and, probably, this negative perception influenced the way in which these citizens view tourism and events.

The four clusters detected by the analysis highlight the different perceptions with respect to tourism in general and the events in Winchester in particular. The cluster 3 (that is strictly connected to the dimension of "tourism supporters") and the cluster 4 (connected to "tourism and outputs") showed the highest value respect to the evaluation on contribution of the events to the local community enjoyment of life. And for these two cluster, the qualitative analysis has showed their evident optimistic vision of life. These results are confirmed also by the regression analyses: the relationship between the latent factor and the residents' perception of the contribution of tourism to the well-being provided by the tourist events shows a negative effects for tourismphobia.

Indeed, variables that usually influence the way in which tourism/events impact on local residents' perception of happiness are: age; gender; income; community attachment and services; length of residence; type of tourists; geographical area; environment aesthetic; crime and overcrowding; health; family; friendship and sentimental situation; and finally, involvements in events [7,11]. Winchester is scoring positively for the different variable. It is one of the least deprived area in England; in 2016, it was the best place to live in England; the crime rate is one of the lowest in the country; life expectancy 
for both men and women is higher than the England average; the city provides a range of events to meet the needs of the locals; and so forth.

\subsection{Key Findings and Contributions}

Based on the above, our first overall conclusion is that there is a relationship between the residents' happiness and tourism/event perception. This study has not shown the direction of the influence but according to previous researches it is the level of happiness of the local residents that determine their perception of the tourism industry and event development and not the other way around. This is to be related to Seraphin et al. [76], who argued that in post-colonial, post-conflict and post-disaster destinations, until the primary needs of the locals are met, there is no point to develop the tourism industry as the locals will not be supportive of the industry. In the same line of thoughts, Dupont [77] also argued that there is a one way direction between tourism development and the reduction of poverty. It is the reduction of poverty that leads to tourism development and not the other way around. Our second overall conclusion is that SITE destinations have a high potential in terms of contributing to the local residents' happiness and subsequently visitors. On that basis, we agree with Croes et al. [14], who are arguing that tourism specialisation improves the residents' quality of life.

Our third and final overall conclusion is that, when the benefits of tourism and events are higher than the cost, local residents and likely to be supportive of the activity and they are likely to be interacting with visitors. These findings are also supported by Cook and Rice [78] but also by Haifeng et al. [79]. The interaction between groups and/or individuals are usually seen as interdependent with the potential to generate high quality relationships [80].

\subsection{Implication for Winchester}

The level of happiness of the residents of a destination is one of the features that contribute to the factor of appeal of a destination [43]. According to Muresan et al. [81], tourism development improves the quality of life of local residents due to its effect on economic development of the area, being useful to the diversification and to the improvement of the general infrastructure. Also in case of agritourism, a key role in sustaining local rural communities has been observed in the case of natural parks [82]. Additionally, Croes et al. [8], claimed that: 'tourists are demanding more unique experiences in making their destination choice and the interaction with locals can shape these unique experiences. The willingness to interact depends on how the locals perceive the impact of tourism on their happiness and satisfaction with life'. This shows that the well-being of locals is equally important as the well-being of visitors as both are interconnected and interdependent. Pera and Viglia [83] also added that community affiliation, personal growth and utilitarian motives also play a significant role in subjective well-being. Happiness is so important that some destinations use it in their marketing [43]. On this line of thought and on the basis that a DMO performance can be assessed on its capacity to inspire travellers to visit their destination [84], happiness could eventually be used as criteria to assess the performance of a DMO.

\subsection{SITE Destinations' Branding as a Way to Avoid Overtourism}

Some destinations are using heritage as part of their branding strategy. Seraphin et al. [85] suggested that capturing the essence of the destination is critical for any visual identification. This branding strategy is also presented as being an alternative to preserve local identity. This strategy seems to be good for local communities. More importantly, if we believe the fact that special interest activities can act as a primary motivating factor in choosing a destination [61], we can come to the conclusion that a destination (like Winchester) branding itself a SITE will attract a specific type of tourists as opposed to any type of tourist, as SITE is to be opposed to mass tourism and will subsequently avoid over tourism. In other words, the fact that destinations are receiving high numbers of visitors that are exceeding their carrying capacity (the maximum limit to tourism development) and causing the destination to suffer strain from tourism. Moreover, local communities are being aware 
of negative effects caused by over tourism and are increasingly interested in their QOL rather than simply in the income generated by tourism industry.

\subsection{Limitations of the Paper and Directions for Future Research}

The principal limitation of the paper is related to the collection method for the data. According to Wright [86], the principal disadvantage in the on line survey is the sampling issues (representativeness of people in online communities, rate responses, etc.) that were forecast in the plan of the research. Despite this limitation, there are different advantages in using the google form (time, cost, access to population) that justify this choice. Furthermore, this type of research is necessary when data is not available in secondary form [15].

Moving on to the direction of future research, in this paper the topic of residents' happiness and QOL need to be associated with the topic of tranquillity. Hewlett et al. [87], taking the example Dorset Area of Outstanding Natural Beauty (AONB) in Southern England, an area close to Hampshire (Winchester), are to some extend claiming that residents' QOL is related to tranquillity and that concept is defined by locals, as the absence of noise, crowding, litter, traffic, pollution; and human activity and the presence of natural environment. This is further supported by Van Niekerk [21]. On that basis, we are claiming that DMOs should consider maintaining protected areas from tourism in any tourism area. These areas should be a natural environment with no human activity [88].

Thus, in order to determine very specifically, the direction and causality between tourism, events development and tranquillity on one side and quality of life of local residents, on the other side, future research should apply the co-integration test of Johansen [89] and causality test of Granger [90].

Author Contributions: Conceptualization, H.S.; Methodology, H.S., G.M. and M.P.; Formal Analysis, G.M. and M.P.; Resources, H.S., G.M. and P.S.; Writing-Original Draft Preparation, all the authors; Writing-Review \& Editing, P.S., G.M. and M.P.

Funding: This research received no external funding.

Acknowledgments: We would like to thank both Winchester Tourist Information Center and WinchesterBid for helping us to collect the data.

Conflicts of Interest: The authors declare no conflict of interest.

\section{Appendix A}

Table A1. Questionaries' items.

\begin{tabular}{l}
\hline Sections $\quad$ Statements \\
\hline sociodemographic information \\
\hline Living residence (express in wards) \\
Age \\
Number of children \\
occupation \\
Gender \\
\hline wellbeing dimension * \\
If I could live my life over, I would change nothing \\
I can find the time to do most everything I want to do \\
I laugh a lot \\
I often think of what I should have done differently in my life \\
I think about the good things that I have missed out on in my life \\
It gives me pleasure to think of my past \\
I make decisions on the spur of the moment \\
It is important to put excitement in my life \\
\hline
\end{tabular}


Table A1. Cont.

\begin{tabular}{|c|c|}
\hline Sections & Statements \\
\hline & $\begin{array}{l}\text { In uncertain times, I usually expect the best } \\
\text { I am always optimistic about my future } \\
\text { Overall, I expect that more good things will happen to me than bad things }\end{array}$ \\
\hline \multicolumn{2}{|c|}{ tourism impact * } \\
\hline & $\begin{array}{l}\text { Tourism brings more investment opportunities to Winchester's economy } \\
\text { Winchester's local businesses benefit from tourism } \\
\text { Tourism creates a variety of jobs in Winchester } \\
\text { Tourism development in Winchester disrupts my life } \\
\text { I see tourists in Winchester as intruders } \\
\text { Tourism growth in Winchester has taken advantage of the community } \\
\text { Tourism increases my pride in my culture } \\
\text { Tourists respect my community's culture } \\
\text { Tourism preserves my community's culture } \\
\text { Tourism in Winchester makes me more conscious of the need to maintain and } \\
\text { improve the appearance of the city } \\
\text { There is a better infrastructure (hotels, car park space, etc) in Winchester due to } \\
\text { tourism development } \\
\text { I am satisfied with the manner in which tourism development and planning in } \\
\text { Winchester is currently taking place } \\
\text { Tourism development is done with the best interests of Winchester and } \\
\text { environment in mind } \\
\text { Tourism in Winchester is a major reason for entertainment and } \\
\text { recreational opportunities }\end{array}$ \\
\hline \multicolumn{2}{|c|}{ Events contribute to the local community enjoyment of life * } \\
\hline & $\begin{array}{l}\text { Architecture (e.g., Winchester Cathedral's Stonemasonry Festival) } \\
\text { Children's (e.g., Children of Winchester Festival) } \\
\text { Christmas (e.g., Winchester Christmas Lights Switch On) } \\
\text { Comedy (e.g., Winchester Comedy Festival, Winchestival) } \\
\text { Fashion (e.g., Winchester Fashion Week) } \\
\text { Film (e.g., Winchester Short Film Festival) } \\
\text { History (e.g., Heritage Open Days) } \\
\text { Horticulture (e.g., Winchester Cathedral's Festival of Flowers) } \\
\text { Food and drink (e.g., Ginchester, Hampshire Food Festival) } \\
\text { Literature (e.g., Winchester Poetry Festival, Winchester Writers Festival) } \\
\text { Music (e.g., Alresford Music Festival, Boomtown, Graze Festival) } \\
\text { Science (e.g., Winchester Science Festival) } \\
\text { Sports (e.g., Winchester Community Games, Winchester Criterium and Cyclefest) } \\
\text { Arts (e.g., Hat Fair, Winchester Festival, Winchester Mayfest)Events development } \\
\text { in Winchester is done with the best interests of the local community and } \\
\text { environment in mind }\end{array}$ \\
\hline
\end{tabular}

$\left(^{*}\right)$ rating scale: from 1 (completely disagree) to 5 (completely agree).

\section{References}

1. Park, S.-Y.; Petrick, J.F. Destinations' Perspectives of Branding. Ann. Tour. Res. 2006, 33, 262-265. [CrossRef]

2. Khoshnevis Yazdi, S.; Khanalizadeh, B. Tourism demand: A panel data approach. Curr. Issues Tour. 2017, 20, 787-800. [CrossRef]

3. Hooper, G.; Lennon, J.L. (Eds.) Dark Tourism: Practice and Interpretation; Routledge: Abingdon/Oxford, UK, 2017.

4. Sanchez, P.M.; Adams, K.M. The Janus-faced character of tourism in Cuba. Ann. Tour. Res. 2008, 35, $27-46$. [CrossRef]

5. Monterrubio, C. Protests and tourism crises: A social movement approach to causality. Tour. Manag. Perspect. 2017, 22, 82-89. [CrossRef] 
6. Seraphin, H.; Yallop, A.C.; Capatîna, A.; Gowreesunkar, V.G. Heritage in tourism organisations' branding strategy: The case of a post-colonial, post-conflict and post-disaster destination. Int. J. Cult. Tour. Hosp. Res. 2018, 12, 89-105. [CrossRef]

7. Ivlevs, A. Happy Hosts? International Tourist Arrivals and Residents' Subjective Well-being in Europe. J. Travel Res. 2017, 56, 599-612. [CrossRef]

8. Croes, R.; Rivera, M.A.; Semrad, K.; Khalizadeh, J. Happiness and Tourism: Evidence from Aruba; The Dick Pope Sr. Institute for Tourism Studies: Orlando, FL, USA, 2017.

9. Kim, K.; Uysal, M.; Sirgy, M.J. How does tourism in a community impact the quality of life of community residents? Tour. Manag. 2013, 36, 527-540. [CrossRef]

10. Benckendorff, P.; Edwards, D.; Jurowski, C.; Liburd, J.J.; Miller, G.; Moscardo, G. Exploring the future of tourism and quality of life. Tour. Hosp. Res. 2009, 9, 171-183. [CrossRef]

11. Bimonte, S.; Faralla, V. Does residents' perceived life satisfaction vary with tourist season? A two-step survey in a Mediterranean destination. Tour. Manag. 2016, 55, 199-208. [CrossRef]

12. Uysal, M.; Sirgy, M.J.; Woo, E.; Kim, H.L. Quality of life (QOL) and well-being research in tourism. Tour. Manag. 2016, 53, 244-261. [CrossRef]

13. Sanchez-Barrios, L.J.; Giraldo, M.; Khalik, M.; Manjarres, R. Services for the underserved: Unintended well-being. Serv. Ind. J. 2015, 35, 883-897. [CrossRef]

14. Croes, R.; Ridderstaat, J.; van Niekerk, M. Connecting quality of life, tourism specialization, and economic growth in small island destinations: The case of Malta. Tour. Manag. 2018, 65, 212-223. [CrossRef]

15. Silver, L.S.; Wrenn, B. The Essentials of Marketing Research, 3rd ed.; Routledge: Abingdon, UK, 2013.

16. Dolnicar, S.; Lazarevski, K.; Yanamandram, V. Quality of life and tourism: A conceptual framework and novel segmentation base. J. Bus. Res. 2013, 66, 724-729. [CrossRef]

17. Kim, H.; Woo, E.; Uysal, M. Tourism experience and quality of life among elderly tourists. Tour. Manag. 2015, 46, 465-476. [CrossRef]

18. Hobson, J.S.P.; Dietrich, U.C. Tourism, Health and Quality of Life. J. Travel Tour. Mark. 1995, 3, 21-38. [CrossRef]

19. McAllister, F. Wellbeing: Concepts and Challenges Discussion Paper; Sustainable Development Research Network: London, UK, 2005.

20. McCabe, S.; Joldersma, T.; Li, C. Understanding the benefits of social tourism: Linking participation to subjective well-being and quality of life. Int. J. Tour. Res. 2010, 12, 761-773. [CrossRef]

21. van Niekerk, M. Community perceptions on the impacts of art festivals and its impact on overall quality of life: A case study of the Innibos National Art Festival, South Africa. In Focus on World Festivals: Contemporary Case Studies and Perspectives; Newbold, C., Jordan, J., Eds.; Goodfellow Publishers Limited: Woodeaton, UK, 2016; p. 333.

22. Rivera, M.; Croes, R.; Lee, S.H. Tourism development and happiness: A residents' perspective. J. Destin. Mark. Manag. 2016, 5, 5-15. [CrossRef]

23. Lyubomirsky, S.; Lepper, H.S. A measure of subjective happiness: Preliminary reliability and construct validation. Soc. Indic. Res. 1999, 46, 137-155. [CrossRef]

24. Helliwell, J.; Layard, R.; Sachs, J. (Eds.) World Happiness Report 2017; Sustainable Development Solutions Network: New York, NY, USA, 2017.

25. Schroeder, K. Cultural Values and Sustainable Tourism Governance in Bhutan. Sustainability 2015, 7, 16616-16630. [CrossRef]

26. Bramwell, B.; Lane, B. (Eds.) Tourism Collaboration and Partnerships: Politics, Practice and Sustainability; Channel View Publications: Clevedon, UK, 2000.

27. Crouch, G.I.; Ritchie, J.R.B. Tourism, Competitiveness, and Societal Prosperity. J. Bus. Res. 1999, 44, 137-152. [CrossRef]

28. Yeoman, I.; Robertson, M.; Ali-Knight, J.; Drummond, S.; McMahon-Beattie, U. (Eds.) Festival and Events Management: An International Arts and Culture Perspective; Elsevier Butterworth-Heinemann: Oxford, UK, 2004.

29. Laing, J. Festival and event tourism research: Current and future perspectives. Tour. Manag. Perspect. 2018, 25, 165-168. [CrossRef]

30. Gursoy, D.; Kendall, K.W. Hosting mega events. Ann. Tour. Res. 2006, 33, 603-623. [CrossRef]

31. Kelly, D.M.; Fairley, S. What about the event? How do tourism leveraging strategies affect small-scale events? Tour. Manag. 2018, 64, 335-345. [CrossRef] 
32. Jago, L.; Dwyer, L.; Lipman, G.; van Lill, D.; Vorster, S. Optimising the potential of mega-events: An overview. Int. J. Event Festiv. Manag. 2010, 1, 220-237. [CrossRef]

33. Andrews, H.; Leopold, T. Events and the Social Sciences, 1st ed.; Routledge: Abingdon, UK; New York, NY, USA, 2013.

34. Richards, G.; Palmer, R. Eventful Cities: Cultural Management and Urban Revitalisation; Butterworth-Heinemann: Oxford, UK, 2010.

35. Seny Kan, A.K.; Adegbite, E.; El Omari, S.; Abdellatif, M. On the use of qualitative comparative analysis in management. J. Bus. Res. 2016, 69, 1458-1463. [CrossRef]

36. Bailey, A.W.; Fernando, I.K. Routine and Project-Based Leisure, Happiness, and Meaning in Life. J. Leis. Res. 2012, 44, 139-154. [CrossRef]

37. Bailey, A.W.; Kang, H.-K.; Schmidt, C. Leisure Routine and Positive Attitudes. J. Leis. Res. 2016, 48, $189-209$. [CrossRef]

38. Bimonte, S.; Faralla, V. Happiness and nature-based vacations. Ann. Tour. Res. 2014, 46, 176-178. [CrossRef]

39. Bimonte, S.; Faralla, V. Tourist types and happiness a comparative study in Maremma, Italy. Ann. Tour. Res. 2012, 39, 1929-1950. [CrossRef]

40. Bimonte, S.; Faralla, V. Happiness and Outdoor Vacations Appreciative versus Consumptive Tourists. J. Travel Res. 2015, 54, 179-192. [CrossRef]

41. Chen, Y.; Li, X.R. Does a happy destination bring you happiness? Evidence from Swiss inbound tourism. Tour. Manag. 2018, 65, 256-266. [CrossRef]

42. Chia, Y.M.; Chu, M.J.T. Moderating effects of presenteeism on the stress-happiness relationship of hotel employees: A note. Int. J. Hosp. Manag. 2016, 55, 52-56. [CrossRef]

43. Gholipour, H.F.; Tajaddini, R.; Nguyen, J. Happiness and inbound tourism. Ann. Tour. Res. 2016, 57, $251-253$. [CrossRef]

44. Gillet, S.; Schmitz, P.; Mitas, O. The Snap-Happy Tourist. J. Hosp. Tour. Res. 2016, 40, 37-57. [CrossRef]

45. Hsiao, J.P.-H.; Jaw, C.; Huan, T.-C.; Woodside, A.G. Applying complexity theory to solve hospitality contrarian case conundrums. Int. J. Contemp. Hosp. Manag. 2015, 27, 608-647. [CrossRef]

46. Khalilzadeh, J.; Ghahramani, L.; Tabari, S. From "Hypercritics" to "Happy Campers": Who Complains the Most in Fine Dining Restaurants? J. Hosp. Mark. Manag. 2017, 26, 451-473. [CrossRef]

47. Kruger, S.; Saayman, M.; Ellis, S. The Influence of Travel Motives on Visitor Happiness Attending a Wedding Expo. J. Travel Tour. Mark. 2014, 31, 649-665. [CrossRef]

48. Lyu, J.; Mao, Z.; Hu, L. Cruise experience and its contribution to subjective well-being: A case of Chinese tourists. Int. J. Tour. Res. 2018, 20, 225-235. [CrossRef]

49. McCabe, S.; Johnson, S. The happiness factor in tourism: Subjective well-being and social tourism. Ann. Tour. Res. 2013, 41, 42-65. [CrossRef]

50. Nawijn, J. The holiday happiness curve: A preliminary investigation into mood during a holiday abroad. Int. J. Tour. Res. 2010, 12, 281-290. [CrossRef]

51. Nawijn, J. Determinants of Daily Happiness on Vacation. J. Travel Res. 2011, 50, 559-566. [CrossRef]

52. Ram, Y.; Nawijn, J.; Peeters, P.M. Happiness and limits to sustainable tourism mobility: A new conceptual model. J. Sustain. Tour. 2013, 21, 1017-1035. [CrossRef]

53. Spiers, A.; Walker, G.J. The Effects of Ethnicity and Leisure Satisfaction on Happiness, Peacefulness, and Quality of Life. Leis. Sci. 2008, 31, 84-99. [CrossRef]

54. Theodorakis, N.D.; Kaplanidou, K.; Karabaxoglou, I. Effect of Event Service Quality and Satisfaction on Happiness Among Runners of a Recurring Sport Event. Leis. Sci. 2015, 37, 87-107. [CrossRef]

55. Tsaur, S.-H.; Yen, C.-H.; Hsiao, S.-L. Transcendent Experience, Flow and Happiness for Mountain Climbers. Int. J. Tour. Res. 2013, 15, 360-374. [CrossRef]

56. Walker, G.J.; Ito, E. Mainland Chinese Canadian Immigrants' Leisure Satisfaction and Subjective Well-Being: Results of a Two-Year Longitudinal Study. Leis. Sci. 2017, 39, 174-185. [CrossRef]

57. Wei, X.; Huang, S.; Stodolska, M.; Yu, Y. Leisure Time, Leisure Activities, and Happiness in China. J. Leis. Res. 2015, 47, 556-576. [CrossRef]

58. Hall, M.; Weiler, B. Introduction. What's special about special interest tourims? In Special Interest Tourism; Hall, M., Weiler, B., Eds.; Bellhaven Press: London, UK, 1992; p. 224.

59. Trauer, B. Conceptualizing special interest tourism-Frameworks for analysis. Tour. Manag. 2006, 27, $183-200$. [CrossRef] 
60. Park, H. Heritage Tourism; Routledge: Abingdon, UK, 2014.

61. Jin, X.C.; Sparks, B. Barriers to offering special interest tour products to the Chinese outbound group market. Tour. Manag. 2017, 59, 205-215. [CrossRef]

62. O'Toole, W. Events Feasibility and Development: From Strategy to Operations; Butterworth-Heinemann: Oxford, UK, 2011.

63. Raj, R.; Walters, P.; Rashid, T. Events Management. Principles E Practice, 3rd ed.; SAGE: Newcastle upon Tyne, UK, 2017.

64. Bowdin, G.; Allen, J.; Harris, R.; McDonnell, I.; O’Toole, W. Events Management, 3rd ed.; Routledge: London, UK, 2012.

65. Holden, A. Tourism, Poverty and Development; Routledge: New York, NY, USA, 2013.

66. Kirillova, K.; Fu, X.; Lehto, X.; Cai, L. What makes a destination beautiful? Dimensions of tourist aesthetic judgment. Tour. Manag. 2014, 42, 282-293. [CrossRef]

67. Naidoo, P.; Sharpley, R. Local perceptions of the relative contributions of enclave tourism and agritourism to community well-being: The case of Mauritius. J. Destin. Mark. Manag. 2016, 5, 16-25. [CrossRef]

68. Pesonen, J.; Komppula, R. Rural Wellbeing Tourism: Motivations and Expectations. J. Hosp. Tour. Manag. 2010, 17, 150-157. [CrossRef]

69. Zografos, C.; Allcroft, D. The Environmental Values of Potential Ecotourists: A Segmentation Study. J. Sustain. Tour. 2007, 15, 44-66. [CrossRef]

70. Konu, H. Identifying potential wellbeing tourism segments in Finland. Tour. Rev. 2010, 65, 41-51. [CrossRef]

71. Dimitrovski, D.; Todorović, A. Clustering wellness tourists in spa environment. Tour. Manag. Perspect. 2015, 16, 259-265. [CrossRef]

72. Pesonen, J.A. Testing Segment Stability: Insights from a Rural Tourism Study. J. Travel Tour. Mark. 2014, 31, 697-711. [CrossRef]

73. McCullagh, P. Regression Models for Ordinal Data. J. R. Stat. Soc. Ser. B 1980, 42, 109-142.

74. Alegre, J.; Cladera, M. Repeat Visitation in Mature Sun and Sand Holiday Destinations. J. Travel Res. 2006, 44, 288-297. [CrossRef]

75. Scott Long, J. Regression Models for Categorical and Limited Dependent Variables; SAGE Publications: Thousand Oaks, CA, USA, 1997.

76. Seraphin, H.; Gowreensunkar, V.; Ambaye, M. The Blakeley Model applied to improving a tourist destination: An exploratory study. The case of Haiti. J. Destin. Mark. Manag. 2016, 5, 325-332. [CrossRef]

77. Dupont, L. Cointégration et causalité entre développement touristique, croissance économique et réduction de la pauvreté: Cas de Haïti [Cointegration and Causality Between Tourist Development, Economic Expansion and proverty reduction in Haiti]. Études Caribéennes 2009, 13-14. [CrossRef]

78. Cook, K.S.; Rice, E. Social Exchange Theory. In Handbook of Social Psychology; Springer US: New York, NY, USA, 2003; pp. 53-76.

79. Haifeng, Y.; Jing, L.; Mu, Z. Rural community participation in scenic spot. A case study of Danxia Mountain of Guangdong, China. J. Hosp. Tour. 2012, 10, 76-112.

80. Cropanzano, R.; Mitchell, M.S. Social Exchange Theory: An Interdisciplinary Review. J. Manag. 2005, 31, 874-900. [CrossRef]

81. Muresan, I.; Oroian, C.; Harun, R.; Arion, F.; Porutiu, A.; Chiciudean, G.; Todea, A.; Lile, R. Local Residents' Attitude toward Sustainable Rural Tourism Development. Sustainability 2016, 8, 100. [CrossRef]

82. Dumitras, D.; Muresan, I.; Ilea, M.; Jitea, I. Agritourism-A Potential Linkage Between Local Communities and Parks to Maintain Sustainability. Bull. UASVM Horitc. 2013, 70, 300-309.

83. Pera, R.; Viglia, G. Turning ideas into products: Subjective well-being in co-creation. Serv. Ind. J. 2015, 35, 388-402. [CrossRef]

84. Gowreesunkar, V.G.B.; Séraphin, H.; Morrison, A. Destination Marketing Organisations: Roles and Challenges. In The Routledge Handbook of Destination Marketing; Gursoy, D., Chi, C.G., Eds.; Taylor \& Francis Ltd.: London, UK, 2018; pp. 16-34.

85. Seraphin, H.; Sheeran, P.; Pilato, M. Over-tourism and the fall of Venice as a destination. J. Destin. Mark. Manag. 2018, 9, 374-376. [CrossRef]

86. Wright, K.B. Researching Internet-Based Populations: Advantages and Disadvantages of Online Survey Research, Online Questionnaire Authoring Software Packages, and Web Survey Services. J. Comput. Commun. 2006, 10, JCMC1034. [CrossRef] 
87. Hewlett, D.; Harding, L.; Munro, T.; Terradillos, A.; Wilkinson, K. Broadly engaging with tranquillity in protected landscapes: A matter of perspective identified in GIS. Landsc. Urban Plan. 2017, 158, 185-201. [CrossRef]

88. Modica, G.; Zoccali, P.; Di Fazio, S. The e-Participation in Tranquillity Areas Identification as a Key Factor for Sustainable Landscape Planning. In Computational Science and Its Applications-ICCSA 2013, Lecture Notes in Computer Science; Murgante, B., Misra, S., Carlini, M., Torre, C.M., Nguyen, H.-Q., Taniar, D., Apduhan, B.O., Gervasi, O., Eds.; Lecture Notes in Computer Science; Springer: Berlin/Heidelberg, Germany, 2013; Volume 7973, pp. 550-565.

89. Johansen, S. Statistical analysis of cointegration vectors. J. Econ. Dyn. Control 1988, 12, 231-254. [CrossRef]

90. Granger, C.W.J. Some recent development in a concept of causality. J. Econom. 1988, 39, 199-211. [CrossRef]

(C) 2018 by the authors. Licensee MDPI, Basel, Switzerland. This article is an open access article distributed under the terms and conditions of the Creative Commons Attribution (CC BY) license (http:/ / creativecommons.org/licenses/by/4.0/). 